INTERNATIONAL JOURNAL OF MULTIDISCIPLINARY RESEARCH AND ANALYSis

ISSN(print): 2643-9840, ISSN(online): 2643-9875

Volume 04 Issue 11 November 2021

DOI: 10.47191/ijmra/v4-i11-40, Impact Factor: 6.072

Page No.- $1728-1731$

\title{
Impact of Anemia on the School Performance of Students at a Public School in Ceará
}

\author{
Larissa Albuquerque Oliveira ${ }^{1}$, Lauhelia Mauriz Marques ${ }^{2}$, Lara Hannyella Gouveia Duarte ${ }^{3}$, \\ Germison Silva Lopes ${ }^{4}$ \\ 1,2,3,4Centro Universitário Christus - Unichristus - R. João Adolfo Gurgel 133 Zip Code: 60190-180
}

\begin{abstract}
INTRODUCTION: Anemia is defined as a condition in which hemoglobin levels are below the normal range. Among children and adolescents, iron deficiency is responsible for most cases. Iron is an essential compound for the production of red blood cells and transportation of oxygen, as well as for the integration of the enzymatic systems of different tissues. Patients with iron deficiency anemia may have impaired cognitive, physical and immune development, thus increasing the risk of infections and even death. This is a cross-sectional study to analyze the prevalence of anemia and its impact on school and nutritional performance among elementary school adolescents aged between 10 and 14 years from May 2019 to October 2019. METHODS: The diagnostic criteria for anemia are: between 5 and 11 years, hemoglobin $<11.5 \mathrm{~g} / \mathrm{dl}$ and hematocrit <34\%; from 12 to 14 years old, hemoglobin $<12 \mathrm{~g} / \mathrm{dl}$ and hematocrit $36 \%$. For school performance, data from the students' individual report card were used and the average of the subjects was considered.. RESULTS: The prevalence of anemia was $9.8 \%$.As for school performance, students with anemia had an average grade of 5.8 , while students without anemia had an average of 6.8 , showing a statistically significant difference $(p=0.02)$. There was also greater absenteeism among students with anemia, $16.1 \%$ of absences, compared to those without anemia, $10.44 \%$ of absences ( $p=0.02$ ). CONCLUSION: The impact on anemia in school performance, correlating it to absenteeism and grades, which reinforces the importance of self-care, a balanced diet and health promotion.
\end{abstract}

\section{INTRODUCTION}

Anemia is defined as a condition in which hemoglobin levels are below the normal range ${ }^{1}$. Among children and adolescents, iron deficiency is responsible for most cases ${ }^{2}$. Iron is an essential compound for the production of red blood cells and transpotation of oxygen, as well as for the integration of the enzymatic systems of different tissues. Patients with iron deficiency anemia may have impaired cognitive, physical and immune development, thus increasing the risk of infections and even death ${ }^{3}$.

The main risk factors for the development of this condition are: age, sex, genetic factors, perinatal conditions, maternal anemia, deficient diet, rapid bone growth, losses and disorders of iron absorption in the gastrointestinal tract (GIT), chronic kidney disease, heart diseases ${ }^{4,5}$.

In Brazil, the prevalence of iron deficiency anemia among children under five years old is $20.9 \%$, being even higher in children under two years old, $24.1 \%^{6}$. Before supplementation was encouraged by the Ministry of Health, the prevalence of iron deficiency reached $53 \%$ of children. Early age was identified as the main risk factor ${ }^{7}$. Among adolescents, the prevalence of anemia is $27 \%$ in developing countries and $6 \%$ in developed countries ${ }^{8}$.

According to World Health Organization (WHO), anemia in schoolchildren must be prevented and tracked, because this condition can negatively affect school performance. Possible reasons to justify are: impaired cognition, inattention and absenteeism. Other diseases, such as infectious, can be present because the immune system is also compromised ${ }^{9}$.

\section{METHODOLOGY}

This is a cross-sectional study to analyze the prevalence of anemia and its impact on school and nutritional performance among elementary school adolescents aged between 10 and 14 years who attended the Papa João XXIII Municipal School, in the city of Fortaleza-CE, from May to October 2019. The study was approved by the local ethics committee.

The sample consisted of all students whose parents agreed to participate in the research and who signed an informed consent form. Students who did not agree to take blood tests or who, during the school year, were transferred to another school unit were excluded from the sample. 


\section{Impact of Anemia on the School Performance of Students at a Public School in Ceará}

The anthropometric parameters analyzed were: body mass index (BMI), waist and abdominal circumference. The measurements of two skinfolds, the triceps and the subscapular, were used to calculate the percentage of body fat. For this calculation, the methodology of Guedes (2000) was used, indicated for measurement in children and adolescents from 7 to 18 years old ${ }^{10}$.

Data on dropout, absenteeism and school repetition were collected from the school system itself. For school performance, data from the students' individual report card was used and the average of the subjects Portuguese, Mathematics, Science, History and Geography was considered.

The diagnostic criteria for anemia are: between 5 and 11 years, hemoglobin $<11.5 \mathrm{~g} / \mathrm{dl}$ and hematocrit $<34 \%$; from 12 to 14 years old, hemoglobin $<12 \mathrm{~g} / \mathrm{dl}$ and hematocrit $36 \%{ }^{11}$.

\section{RESULTS}

Data from 61 adolescents were evaluated, of which $65.6 \%$ were female and $34.4 \%$ male. The prevalence of anemia was $9.8 \%$. The average age of students was 11 years. The mean hemoglobin and hematocrit were, respectively, $13.2 \mathrm{~g} / \mathrm{dL}$ and $40.8 \%$. The average grade of the students was 6.68 . The average percentage of absenteeism was $11 \%$. As for anthropometric data, the mean BMI was $20.18 \mathrm{~m}^{2}$ and the mean percentage of body fat was $25.47 \%$. The mean of the demographic data with respective standard deviations are summarized in table 1.

TABLE 1- Epidemiological profile of the evaluated students

\begin{tabular}{lll}
\hline & Average & Standard deviation( \pm ) \\
\hline Age years) & 11 & 1 \\
HEMOGLOBIN(g/ dL ) & 13.2 & 0.9 \\
HEMATOCRIT(\%) & 40.86 & 2.52 \\
GRADES & 6.68 & 1.21 \\
\%Lack & 11.00 & 5.91 \\
BMI & 20.18 & 4.67 \\
FAT PERCENTAGE (\%) & 25.47 & 7.14 \\
\hline
\end{tabular}

As for school performance, students with anemia had an average grade of 5.8, while students without anemia had an average of 6.8 , showing a statistically significant difference $(p=0.02)$, as shown in Figure 1.

There was also greater absenteism among students with anemia, $16.1 \%$ of absences, compared to those without anemia, $10.44 \%$ of absences $(p=0.02)$.

There was no statistically significant difference between students with and without anemia and anthropometric parameters such as BMI ( $p=0.51)$ and percentage of body fat $(p=0.58)$. Table 2 summarizes the statistical analysis of students with and without anemia and its impact on school performance and nutritional profile.

Figure 1: Impact of anemia on performance of elementary school students

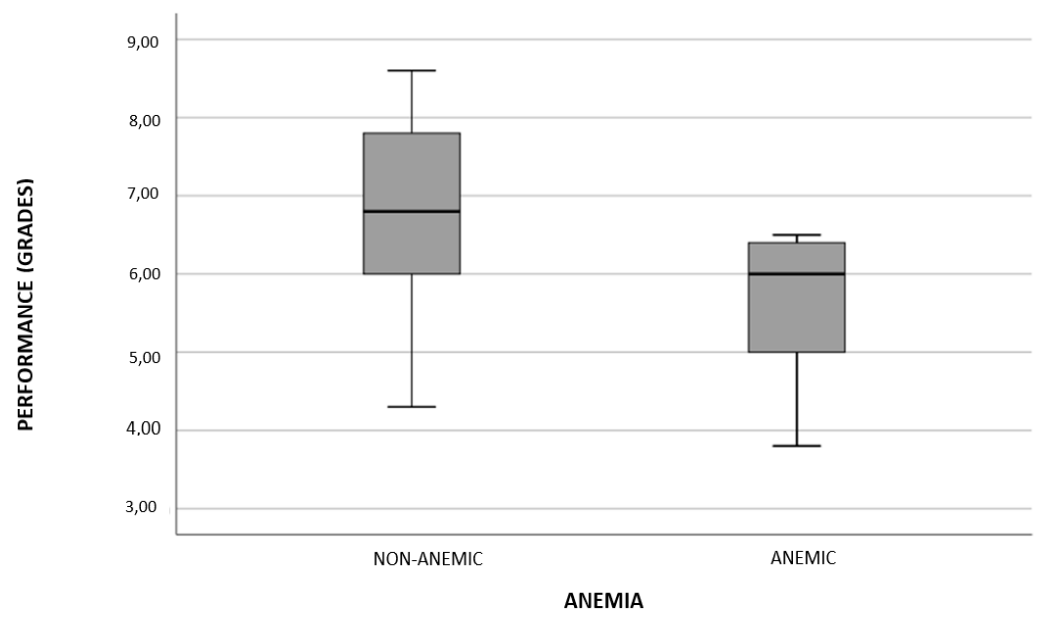

School performance of students with anemia was significantly lower than those without anemia $(p=0,02)$. 
Impact of Anemia on the School Performance of Students at a Public School in Ceará

TABLE 2 - Comparison of school performance and nutritional profile between students with and without anemia

\begin{tabular}{|c|c|c|c|c|c|}
\hline & \multicolumn{2}{|c|}{ STUDENTS WITHOUT ANEMIA } & \multicolumn{2}{|c|}{ STUDENTS WITH ANEMIA } & \multirow[b]{2}{*}{$p$ value } \\
\hline & Average & $\begin{array}{l}\text { Standard } \\
\text { deviation }\end{array}$ & Average & $\begin{array}{l}\text { Standard } \\
\text { deviation }\end{array}$ & \\
\hline INCOME (GRADES) & 6.80 & 1.18 & 5.62 & 1.04 & 0.02 \\
\hline$\%$ abscense & 10.44 & 5.46 & 16.10 & 7.84 & 0.03 \\
\hline BMI & 20.05 & 4.49 & 21.37 & 6.45 & 0.51 \\
\hline FAT PERCENTAGE ( \%) & 25.64 & 7.23 & 23.91 & 6.60 & 0.58 \\
\hline
\end{tabular}

\section{DISCUSSION}

Anemia is one of the biggest public health problems in Brazil and in the world. Iron deficiency is the most common cause in children. This condition is very important because iron is necessary for the complete myelination of sensory neurons, which is related to learning and behavior, in addition to a drop in immunity and susceptibility to infections ${ }^{12}$.

In this study, anemia has been observed in $9.8 \%$ of the students, showing that there was a low prevalence of anemia in the evalueted students, in agreement with the results of Spezia et. al (2018) and Novaes et. al. (2017), who also found a prevalence of anemia of, respectively, $2.2 \%$ and $10.2 \%$, respectively ${ }^{12,13}$. In a meta-analysis comprising eight national studies with children attending day care centers, the prevalence of anemia ranged from 35.0 to $68.8 \%$, higher than that found in the present study, but analyzing a younger population ${ }^{14}$. Rocha et al. (2012) found an prevalence of anemia of $30.2 \%$ (children and adolescents aged 8 - 14 years) and Semedo et. al. (2014) observed a prevalence of $23.8 \%$ (children and adolescents aged 10 14 years) ${ }^{15,16}$.

As for the influence on school performance, this study found a statistically significant difference between students with and without anemia. Indicating that students with anemia had a higher frequency of absences $(p=0.03)$ and lower school performance $(p=0.02)$, when compared to students without anemia. These results disagreed with the results of Spezia et. al. (2018) who found no statistically significant difference between these variables ${ }^{12}$.

As will nutritional assessment, this study showed that the average BMI of school was $20,18 \mathrm{~kg} / \mathrm{m}^{2}$ and the average fat percentage was $25.47 \%$, which indicates overweight. Most of the population studied has a higher percentage of fat than expected for their age group. In the study by Camillo et.al.(2010), which compared the prevalence of anemia in schoolchildren and its relationship with anthropometric data, it showed that the lower the BMI $(\mathrm{W} / \mathrm{H})$, the greater the degree of malnutrition and the higher the prevalence of anemia, with statistical significance between groups $(p=0.002)$. This same study also showed that the child's age is a determining factor in the risk of occurrence of iron deficiency ${ }^{17}$. Oliveira et.al. (2012) observed that the higher the percentage of fat, there is also a greater chance of developing anemia, demonstrating that children who had a higher percentage of fat, they also had lower hemoglobin concentrations $(p=0.003)$. The explanation for this finding is the inadequate food consumption of these individuals, based on foods rich in salt, sugars and fats and with low intake of vitamins and minerals. Another point to be considered is that the obese child has an inflammatory state with high release of cytokines, which would reduce the body's use of iron, causing anemia. In this case, interleukin 6 (IL-6) would play an important role in the stimulation of hepcidin , a hormone responsible for the lower release of iron by enterocytes and macrophages, and, consequently, for the lower absorption of this mineral by the body ${ }^{18}$.

This study had some limitations, such as the small population, due to low parental adherence in signing the free and informed consent form. In addition, there was difficulty in transporting the studied children to the laboratory to perform the erythrogram. Another limitation of the study was related to nutritional assessment, in which BMI and fat percentage were assessed using anthropometric measures, in which many children were absent, or even some of them had transferred from school, and this limited the population to be studied.

\section{CONCLUSION}

This was a pioneering study in the city of Fortaleza, Ceará state, because he has sought to analyze the impact on anemia in school performance, correlating it to absenteeism and grades. The contributing to endorse the continuation of coping with anemia in schoolchildren. It was not the scope of this work to analyze the etiology of anemia, but all patients with anemia were referred for specialized evaluation. The interaction between professors and students and researchers strengthened the ties between them, reinforcing the importance of self-care, a balanced diet and health promotion. 


\section{Impact of Anemia on the School Performance of Students at a Public School in Ceará}

\section{REFERENCES}

1) da Silva LLS, Fawzi WW, Cardoso MA, ENFAC Working Group (2018) Factors associated with anemia in young children in Brazil. PLoS ONE 13(9): e0204504. https://doi.org/10.1371/journal.pone.0204504.

2) Spezia J, Carvalho LF, Camargo-Filho MF, Furman AE, Utiyama SR, Henneberg R. Prevalence of anemia in schools of the metropolitan region of Curitiba, Brazil. Hematology, Transfusion and Cell Therapy [Internet]. 2018 Abr [citado 14 jul 2021];40(2):151-5. Disponível em: https://doi.org/10.1016/j.htct.2017.11.007.

3) Zuffo CR, Osório MM, Taconeli CA, Schmidt ST, da Silva BH, Almeida CC. Prevalence and risk factors of anemia in children. Jornal de Pediatria [Internet]. 2016 Jul [citado 14 jul 2021];92(4):353-60. Disponível em: https://doi.org/10.1016/j.jped.2015.09.007.

4) Baker RD, Greer FR; Committee on Nutrition American Academy of Pediatrics. Diagnosis and prevention of iron deficiency and iron-deficiency anemia in infants and young children (0-3 years of age). Pediatrics. 2010 Nov;126(5):1040-50. doi: 10.1542/peds.2010-2576.

5) Camaschella C. New insights into iron deficiency and iron deficiency anemia. Blood Rev. 2017 Jul;31(4):225-233. doi: 10.1016/j.blre.2017.02.004. Epub 2017 Feb 13. PMID: 28216263.

6) Protocolo Clínico e Diretrizes Terapêuticas: Anemia Por DeFiciência De Ferro [Internet]. Brasília-DF: MS; 2014 [cited 2021 Jul 5]. 20 p. Available from:

http://conitec.gov.br/images/Consultas/Relatorios/2014/pcdt_Anemia_DeficienciaFerro_2014.pdf.

7) Jordão, Regina Esteves, Bernardi, Júlia Laura D. e Barros Filho, Antônio de AzevedoPrevalência de anemia ferropriva no Brasil: uma revisão sistemática. Revista Paulista de Pediatria [online]. 2009, v. 27, n. 1 [Acessado 14 Julho 2021] , pp. $90-$ 98. Disponível em: <https://doi.org/10.1590/S0103-05822009000100014>. Epub 27 Mar 2009. ISSN 1984-0462. https://doi.org/10.1590/S0103-05822009000100014.

8) Işık Balcı Y, Karabulut A, Gürses D, Ethem Çövüt I. Prevalence and Risk Factors of Anemia among Adolescents in Denizli, Turkey. Iran J Pediatr. 2012 Mar;22(1):77-81.

9) SIXTY-EIGHTH WORLD HEALTH ASSEMBLY [Internet]. Geneva; 2015 May 28. OMS WHA68.19 ? Resultados da Segunda Conferência Internacional sobre Nutrição; [cited $2021 \mathrm{Jul}$ 6]; Available from: https://apps.who.int/gb/ebwha/pdf_files/WHA68-REC1/A68_R1_REC1-en.pdf.

10) Guedes DP, Rechenchosky L. Comparação da gordura corporal predita por métodos antropométricos: Índice de massa corporal e espessuras de dobras cutâneas. Revista Brasileira de Cineantropometria e Desempenho Humano [Internet]. 1 fev 2008 [citado 10 ago 2021];10(1):1. Disponível em: https://doi.org/10.5007/1980-0037.2008v10n1p1

11) Programa Nacional de Suplementação de Ferro: Manual de condutas gerais [Internet]. 1st ed. Brasília-DF: MS; 2013 [cited 2021 Jul 1]. 24 p. ISBN: 9788533420427 . Available from:

189.28.128.100/dab/docs/portaldab/publicacoes/manual_ferro2013.pdf.

12) Spezia J, Carvalho LF, Camargo-Filho MF, Furman AE, Utiyama SR, Henneberg R. Prevalence of anemia in schools of the metropolitan region of Curitiba, Brazil. Hematology, Transfusion and Cell Therapy [Internet]. 2018 Abr [citado 14 jul 2021]; 40(2):151-5. Disponível em: https://doi.org/10.1016/j.htct.2017.11.007.

13) Novaes TG, Gomes AT, Silveira KC, Magalhães El, Souza CL, Netto MP, Lamounier JA, Rocha Dd. Prevalência e fatores associados à anemia em crianças de creches: uma análise hierarquizada. Revista Paulista De Pediatria [Internet]. 31 jul 2017 [citado 14 jul 2021];35(3):281-8. Disponível em: https://doi.org/10.1590/1984-0462/;2017;35;3;00008.

14) Vieira RC, Ferreira Hd. Prevalência de anemia em crianças brasileiras, segundo diferentes cenários epidemiológicos. Revista de Nutrição [Internet]. 2010 Jun [citado 14 jul 2021];23(3):433-44. Disponível em: https://doi.org/10.1590/s141552732010000300011.

15) Rocha Dd, Capanema FD, Pereira Netto M, Franceschini Sd, Lamounier JA. Prevalência e fatores determinantes da anemia em crianças assistidas em creches de Belo Horizonte - MG. Revista Brasileira de Epidemiologia [Internet]. 2012 Set [citado 14 jul 2021];15(3):675-84. Disponível em: https://doi.org/10.1590/s1415-790x2012000300020.

16) Semedo, M., Santos, M.J., Baião, M.R., Luiz, R., \& Veiga, G.V. (2014). Anemia and associated factors among school-age children in Cape Verde, West Africa. African Journal of Food, Agriculture, Nutrition and Development, 14, 9511-9528.

17) Camillo CC, Amancio OM, Vitalle MS, Braga JA, Juliano Y. Anemia ferropriva e estado nutricional de crianças de creches de Guaxupé. Revista da Associação Médica Brasileira [Internet]. 2008 Abr [citado 30 jul 2021];54(2):154-9. Disponível em: https://doi.org/10.1590/s0104-42302008000200020.

18) Oliveira MA, Osório MO. Consumo de leite de vaca e anemia ferropriva na infância. J Pediatr (Rio J). 2005;81: 361-7. 